\title{
ASSESSMENT
}

\section{Comparing Two Models of Undergraduate Research Using the OSCAR Student Survey}

\author{
Stephanie L. Foster, Bethany M. Usher, \\ George Mason University
}

\begin{abstract}
This article discusses George Mason University's locally developed assessment survey instrument, the OSCAR Student Survey, in which students self-report on learning outcomes, attitudes, goals, personal and professional growth, and satisfaction items. Development of the instrument is discussed, as well as the methods used to achieve construct validity. Results are compared from 2013-2016 student participation in the individually mentored Undergraduate Research Scholars Program (URSP) and Mason's Research- and Scholarship-Intensive (RS) courses, which are capstone-style research courses for seniors. Both groups reported highly positive attitudes and experiences overall, yet an independent samples Mann-Whitney $U$ test revealed that URSP students reported significantly more positive attitudes about doing research, and more personal and professional development at the end of their experience. URSP students reported dramatically higher rates of learning on several inquiry outcomes. Limitations and implications for use in program assessment are presented.
\end{abstract}

Keywords: assessment, learning outcomes, program outcomes, survey, undergraduate research

\section{doi: 10.18833/spur/1/3/6}

In the decade since Kuh (2008) began promoting undergraduate research as a "high-impact educational practice," undergraduate research programs have proliferated at American colleges and universities. Although there has been a growing scholarship on the contribution of undergraduate research participation to student success and learning, programs often are challenged by the task of assessing the impact of their efforts for their own students.
It becomes especially challenging as programs expand beyond STEM fields into other disciplines, where the mentoring models and expectations for student performance outcomes can differ. At George Mason University (Mason), more than 1,100 students each year engage in an intensive research experience, either through course-based research or individually mentored projects across diverse disciplines. Assessment has been foundational to the initiative, contributing to thoughtful program development and to the improvement of teaching and learning. This article discusses one assessment strategy, the OSCAR Student Survey, including development, comparison of results from two programs that use the same learning outcomes, and implications for use in program assessment.

\section{Students as Scholars: An Undergraduate Research Initiative}

In 2011, George Mason University launched the Students as Scholars initiative with the mission to transform the university culture through increased participation and celebration of undergraduate research and creative activities. Now in its sixth year, Students as Scholars has transformed Mason's approach to undergraduate education. Through inquiry-led courses and experiential learning opportunities across the curriculum, 10,000 students each year learn about the processes of discovery, including how to develop scholarly questions, use appropriate research methods, engage in ethical practice, and situate scholarly work in a broader context. Students as Scholars works with faculty to develop courses and mentored experiences for students throughout the college experience. These experiences are developed using a set of developmental student learning outcomes that provide an essential framework for learning across disciplines. This starts with discovery of how 
FIGURE 1. Scaffolded Model and Student Learning Outcomes of the Students as Scholars Program

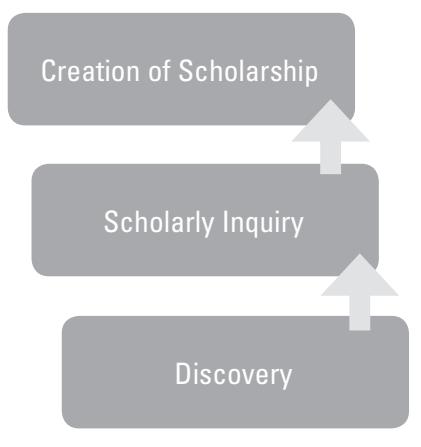

Student Learning Outcomes (SLO)

SLO 3. Create an original scholarly project and communicate knowledge from the scholarly or creative project. (Research and Scholarship Intensive)

SLO 2. Engage in elements of scholarly inquiry. (Scholarly Inquiry)

SLO 1. Understand the value of knowledge and how it is generated and communicated. (Discovery)

UNIVERSAL SLO. Discover how students can engage in the practice of scholarship.

knowledge is created, building to the practice of scholarly inquiry and expanding capacity to create an original or authentic scholarly project through a research- and scholarship-intensive experience (see Figure 1). Students as Scholars is conducted through the Office of Student Scholarship, Creative Activities, and Research (OSCAR).

In this article, survey results are compared for OSCAR's two main research- and scholarship-intensive programs: the RS course and the Undergraduate Research Scholars Program (URSP). The two programs are designed to address the same set of learning outcomes but use different instructional models. RS courses are taught in academic departments across the curriculum, enrolling 10-40 students in each class for a capstone-style research experience. Students typically take the RS course in their major or concentration and earn an RS designation on their transcript for successfully identifying a project, independently carrying out a significant portion of the project, and presenting the results to an external audience. The competitive-admission URSP matches student-scholars with faculty to plan and carry out an individually mentored, original research project. The URSP requires 40 hours of work per week for the summer program and 12 hours per week for those choosing the academic-year program. Students and mentors each receive stipends and a small budget for supplies.

\section{OSCAR Student Survey}

The OSCAR Student Survey is a self-report survey instrument designed to assess program outcomes and student learning outcomes for Students as Scholars as part of a program-level assessment strategy. The instrument was developed in-house to align with the program outcomes and student learning outcomes (see Figure 1). These outcomes were developed using the literature on student learning in inquiry-led experiences and support essential learning such as critical thinking, written and oral communication, and ethical practices (George Mason University Students as Scholars Initiative 2016). Because existing surveys did not meet identified needs, an instrument was developed based on strengths of surveys at other institutions.
Suitable items were adopted or adapted from Lopatto (2004, 2010, 2012a, 2012b, 2012c) and Spronken-Smith et al. (2012), as well as unpublished instruments from Cornell University (2011) and Gettysburg College (2011). Several items created also were used on Mason's Graduating Senior Survey (2012), which allows for an analysis of multiple data points for the same individuals over time. Survey item categories include attitudes and opinions about research and creative activities, goals and plans for the future, opportunities and motivation for undergraduate research, knowledge and skills learned from the experience, personal development, and the research experience.

The survey is conceptualized as one instrument with three parts: Discovery Set, Course Set, and Individualized Scholarly Experience Set. Each set contains items that measure student perception of their experience against the relevant learning outcomes. Students receive the set that corresponds to their experience: students in a Discovery course or experience only receive the Discovery set, students completing a Scholarly Inquiry or RS course receive the Discovery and Course sets, and students completing the URSP or other individually-mentored experience receive the Discovery and Individualized Scholarly Experience sets. The survey is administered via a unique survey link with a personalized email invitation at the end of the semester in which students have completed an OSCAR course or experience. Individual survey responses are linked with a Mason ID number to allow for merging with student demographic variables.

Survey data are collected from students at several points: during the first-year orientation course (UNIV 100); during the required advanced composition course (ENGH 302); during a Discovery, Inquiry, or RS course; and during participation in the URSP, OSCAR Research Assistant Program, or research-designated independent study credits. A subset of items also appears on Mason's Graduating Senior Survey. It is thus possible to collect survey data from students at multiple times throughout their college years, allowing insight into their attitudes and reports of 
their learning changes over time. More than 10,000 participants are surveyed each year through their involvement in OSCAR activities. It is hoped that these longitudinal data will help build understanding of student development over time and identify the experiences that have had the most impact. Approval is sought each year from the institution's Human Subjects Research Board to administer the survey and use the data beyond institutional reporting.

\section{Validity of the Survey Instrument}

Validity for surveys typically concerns construct validity - that is, whether the instrument measures what it is intended to measure. Because the OSCAR Student Survey was created to be primarily a program assessment tool, the form of construct validity known as response process validity was of primary concern, as it provides information about whether the participants interpret the items and use the same thought process as the creators intended. When used in the development phase, this information assists in item revision and clarification of instructions to participants before the survey is used with the target population. The OSCAR Student Survey underwent two pilot studies to test and refine the instrument. In Pilot 1, longer versions of the Discovery and Individualized Scholarly Experience sets were administered to URSP students in summer 2012, and the Discovery set was also administered to UNIV 100 first-year students at the beginning of fall 2012. A factor analysis of the resulting data identified highly correlated items that behaved as duplicates, and thus scales could be reduced to essential items. A series of small focus groups based on cognitive interviewing techniques (Willis 1999) was conducted with Pilot 1 survey participants. Participants were guided through the survey items and were interviewed about their responses. Guiding questions included the following:

- Do the items make sense, or is there better wording?

- Do the questions give you the opportunity to respond accurately about your perceptions and experiences?

- Are there response options that we overlooked for each question? and

- Is there something you would like to tell us about your research experiences that we did not ask about?

Recordings of the focus groups were transcribed and analyzed for themes (with the participation of our own undergraduate researcher). This process provided rich, qualitative data that informed item revision. Survey items were revised following analysis of Pilot 1 results.

The revised survey was administered to OSCAR students in a second pilot study (Pilot 2) at the end of fall 2012. At this time, there were two scales for which wording had been particularly challenging to clarify in Pilot 1. Cognitive interviews with individuals following the previous focus group protocol yielded information that assisted in further refining those scales. The survey was again revised, and the final version launched with the full population at the end of spring 2013.

\section{Results and Discussion}

Responses were compared to the common survey items for respondents enrolled in RS courses and the URSP for academic years 2013-2016 (four years). Because students may have completed the survey for more than one course or experience during that time, only their first-time responses were used in the analysis. Samples are independent; no student in the sample took the survey for both RS and URSP. Survey respondents included 917 RS students and 243 URSP students for response rates of 30 percent and 58 percent respectively. Respondents were primarily seniors ( 85 percent for RS and 79 percent for URSP) when they completed the survey. Respondents were slightly more likely to be female than nonrespondents for RS only (55 percent respondents versus 50 percent in the full population). There were no differences between respondents and nonrespondents in terms of racial composition. Mason enrolls a significant population of transfer students, most of whom start their postsecondary education at the regional community college. In the study population, URSP students were more likely than RS students to have started at Mason as first-year students (64 percent versus 44 percent, respectively), representing a potential important distinction between the two groups. RS courses represented disciplines in the sciences, social sciences, humanities, engineering, and social work.

All responses were compared between RS and URSP groups on three sets of items: attitudes about research; learning outcomes for Discovery, Scholarly Inquiry, and Creation of Scholarship (Research and Scholarship Intensive); and contribution of the experience to personal development. Data were compared using the nonparametric Mann-Whitney $U$ Test because the response data are ordinal (i.e., Likert-scale responses such as "strongly agree" and "disagree") and are not normally distributed (responses skew toward the positive). Mann-Whitney compares the outcomes between two independent groups-in this case, RS and URSP - to determine whether the two groups report the same or different outcomes. Mann-Whitney $U$ is the nonparametric equivalent of the independent samples $t$-test and does not assume a normal distribution. MannWhitney $U$ uses the median as a measure of central tendency calculated using the mean sum of ranks. In Tables $1-5$, for each set of results, the group with the higher mean rank and significance value $p<.05$ (two-tailed) report more positive or higher outcomes on the Likert-scale and are considered statistically significant.

\section{Attitudes}

The OSCAR Student Survey asks students to rate their level of agreement on a four-point Likert scale ("strongly 
agree" = 4, "agree" = 3, "disagree" = 2, and "strongly disagree" = 1) for 13 attitudinal items about research and creative activities. Responses for all items for both groups were high, with 85 to 98 percent reporting "agree" to "strongly agree" on all research-positive items such as "advances in research can solve real-life problems," "learning about proper research methods and techniques is a valuable use of time," and "I take pleasure in learning about a subject in-depth." Fewer than 10 percent agreed or strongly agreed with research-negative items such as "helping a professor with her/his research would be a waste of my time." Although the responses were highly positive for both groups, Mann-Whitney $U$ analysis revealed significant differences between groups for all items except one: "I enjoy learning about people and experiences that are different from my own." For all 12 remaining items, URSP students reported more positive attitudes than RS students (see Table 1).

\section{Discovery Learning Outcomes}

Students were asked to reflect on their RS course or URSP semester and rate the contribution of the course or experience to their learning for each of the three levels of learning outcomes on a five-point scale ("very much" $=4$, "quite a bit" = 3, "some" = 2, "very little" = 1 , and "none/not applicable" is treated as missing). The Discovery scale includes eight items that delineate the Discovery learning outcome, "understand the value of knowledge and how it is generated and communicated." Analysis revealed no difference between RS and URSP groups on six of the eight items, including "judging the quality of research studies or creative works" and "understanding the research or creative process in your field." Significant differences between the groups were found on two items, for which URSP rated the experience higher: "explaining the advantages and limitations of different methods to approaching a question or problem in your field," and "career or work-related knowledge and skills" (see Table 2).

\section{Scholarly Inquiry and Research- and Scholarship-Intensive Learning Outcomes}

Nine items compose the learning scale that supports the Scholarly Inquiry learning outcome, "engage in elements of scholarly inquiry." Significant differences were found for six of the nine items, with the URSP participants reporting a higher contribution to their learning for all items, such as "dealing with obstacles faced in the research or creative process"; "analyzing data and information relevant to the project"; and "communicating well orally in a presentation, performance, or discussion of your work" (see Table 3). No differences were found between the groups for matching a question to method, learning ethical conduct, or collecting data. Similar differences were revealed for the two items supporting the Researchand Scholarship-Intensive learning outcome, "create an original scholarly project and communicate knowledge from the scholarly or creative project." On both items ("articulating the broad implications or 'big picture' of what you learned in the course or project" and "creating new ideas, solutions, or creative works based on what you learned in the course or experience"), URSP respondents reported that their experience contributed significantly more to their learning than the RS respondents ("quite a bit" and "very much": 75 percent for URSP and 36 percent for RS). See Table 4.

\section{Personal Development}

As the development of personal and interpersonal skills and competencies go hand-in-hand with a student's academic development, students were asked to respond to seven items regarding personal development. Responses were based on a five-point scale ("very much" $=4$, "quite a bit" = 3, "some" = 2, "very little" = 1, and "none/not applicable" is treated as missing). Analysis revealed significant differences on four of the seven items, with URSP students again reporting greater gains on all four items such as "being patient with the pace of research or creative discovery," "confidence in your ability to contribute to your field," and "maintaining a curious attitude." No differences were found between the groups for "relating well to people of different races, nations, and religions"; "comfort in working collaboratively with others"; and "managing your time effectively" (see Table 5).

Overall, the results are not surprising but do inform the institution's undergraduate research work in important ways. The RS and URSP experiences are both crafted to address the same learning outcomes so that mentored experiences can be provided that support students to develop increasing autonomy in their research or creative endeavors. But differences can be observed between the groups that may explain many of the differences revealed in the comparison analysis. The primary difference is in how the groups come to be involved: students must apply to the URSP and be selected for the program, whereas other students enroll in RS courses without undergoing a selection process. The URSP is moderately selective (not all applicants are accepted), students must take initiative to find a mentor who agrees to work with them, and they must plan ahead at least one full semester to allow for the project planning and selection process. Many of the URSP students have worked with their faculty mentor or their subject matter in a previous course or research experience. On the other hand, RS courses are taught in departments and may be a required course for all students (such as a capstone course) or may be an option for students enrolled in a certain concentration or track. These differences in self-selection may account for much of the difference in student experience as reported in the survey. Additionally, differences may result from the different mentoring and interpersonal arrangements: some 
TABLE 1. Comparison of RS and URSP on Reported Attitudes About Research and Creative Activities

\begin{tabular}{|c|c|c|c|c|c|c|c|}
\hline Items & Group & $\mathrm{N}$ & Mean Rank & Sum of Ranks & $\begin{array}{c}\text { Mann-Whitney } \\
\text { U }\end{array}$ & Z & $\begin{array}{l}\text { Asymp. Sig. } \\
\text { (2-tailed) }\end{array}$ \\
\hline \multirow{3}{*}{$\begin{array}{l}\text { I enjoy learning about people } \\
\text { and experiences that are } \\
\text { different from my own }\end{array}$} & $\mathrm{RS}$ & 863 & 539.35 & 465461.50 & \multirow{3}{*}{92645.500} & \multirow{3}{*}{-1.478} & \multirow{3}{*}{0.140} \\
\hline & URSP & 227 & 568.87 & 129133.50 & & & \\
\hline & Total & 1090 & & & & & \\
\hline \multirow{3}{*}{$\begin{array}{l}\text { Laws and policy decisions } \\
\text { should be based on research } \\
\text { findings }\end{array}$} & $\mathrm{RS}$ & 828 & 504.59 & 417801.00 & \multirow{3}{*}{74595.000} & \multirow{3}{*}{-2.915} & \multirow{3}{*}{$0.004 *$} \\
\hline & URSP & 204 & 564.84 & 115227.00 & & & \\
\hline & Total & 1032 & & & & & \\
\hline \multirow{3}{*}{$\begin{array}{l}\text { Advances in research can solve } \\
\text { real-life problems }\end{array}$} & $\mathrm{RS}$ & 828 & 492.98 & 408189.00 & \multirow{3}{*}{64983.000} & \multirow{3}{*}{-5.952} & \multirow{3}{*}{$0.000 *$} \\
\hline & URSP & 204 & 611.96 & 124839.00 & & & \\
\hline & Total & 1032 & & & & & \\
\hline \multirow{3}{*}{$\begin{array}{l}\text { Most research focuses on } \\
\text { problems that are too } \\
\text { insignificant to really mean } \\
\text { anything }\end{array}$} & $\mathrm{RS}$ & 861 & 566.87 & 488078.50 & \multirow{3}{*}{79320.500} & \multirow{3}{*}{-5.001} & \multirow{3}{*}{$0.000^{*}$} \\
\hline & URSP & 228 & 462.40 & 105426.50 & & & \\
\hline & Total & 1089 & & & & & \\
\hline \multirow{3}{*}{$\begin{array}{l}\text { Learning about proper research } \\
\text { methods and techniques is a } \\
\text { valuable use of time }\end{array}$} & $\mathrm{RS}$ & 862 & 520.09 & 448315.00 & \multirow{3}{*}{76362.000} & \multirow{3}{*}{-5.848} & \multirow{3}{*}{$0.000 *$} \\
\hline & URSP & 228 & 641.58 & 146280.00 & & & \\
\hline & Total & 1090 & & & & & \\
\hline \multirow{3}{*}{$\begin{array}{l}\text { Participating in the creation or } \\
\text { discovery of new knowledge is } \\
\text { personally rewarding }\end{array}$} & $\mathrm{RS}$ & 862 & 516.04 & 444824.50 & \multirow{3}{*}{72871.500} & \multirow{3}{*}{-7.027} & \multirow{3}{*}{$0.000 *$} \\
\hline & URSP & 228 & 656.89 & 149770.50 & & & \\
\hline & Total & 1090 & & & & & \\
\hline \multirow{3}{*}{$\begin{array}{l}\text { Helping a professor with her/his } \\
\text { research would be a waste } \\
\text { of my time }\end{array}$} & $\mathrm{RS}$ & 826 & 537.89 & 444300.00 & & & \\
\hline & URSP & 204 & 424.83 & 86665.00 & 65755.000 & -5.338 & $0.000 *$ \\
\hline & Total & 1030 & & & & & \\
\hline Learning about research or & $\mathrm{RS}$ & 855 & 513.91 & 439389.00 & & & \\
\hline $\begin{array}{l}\text { creative works makes me more } \\
\text { curious about the world }\end{array}$ & URSP & 228 & 647.36 & 147597.00 & 73449.000 & -6.388 & $0.000 *$ \\
\hline & Total & 1083 & & & & & \\
\hline It is fun to work on problems & $\mathrm{RS}$ & 855 & 510.28 & 436285.50 & & & \\
\hline $\begin{array}{l}\text { that cannot be easily solved or } \\
\text { that take a long time to solve }\end{array}$ & URSP & 228 & 660.97 & 150700.50 & 70345.500 & -7.032 & $0.000 *$ \\
\hline & Total & 1083 & & & & & \\
\hline I take pleasure in learning about & $\mathrm{RS}$ & 855 & 515.56 & 440803.00 & & & \\
\hline & URSP & 228 & 641.15 & 146183.00 & 74863.000 & -6.133 & $0.000 *$ \\
\hline & Total & 1083 & & & & & \\
\hline Participating in research or & RS & 855 & 503.72 & 430676.50 & & & \\
\hline $\begin{array}{l}\text { creative activities improves the } \\
\text { academic experience }\end{array}$ & URSP & 228 & 685.57 & 156309.50 & 64736.500 & -8.858 & $0.000 *$ \\
\hline & Total & 1083 & & & & & \\
\hline Being involved in research or & RS & 855 & 511.62 & 437438.00 & & & \\
\hline $\begin{array}{l}\text { creative activities can help me } \\
\text { become a better professional in }\end{array}$ & URSP & 228 & 655.91 & 149548.00 & 71498.000 & -7.283 & $0.000 *$ \\
\hline my field & Total & 1083 & & & & & \\
\hline Professors who do their own & $\mathrm{RS}$ & 818 & 497.29 & 406779.50 & & & \\
\hline $\begin{array}{l}\text { research or creative works make } \\
\text { better teachers }\end{array}$ & URSP & 204 & 568.50 & 115973.50 & 71808.500 & -3.363 & $0.001 *$ \\
\hline & Total & 1022 & & & & & \\
\hline
\end{tabular}

Note: Mann-Whitney U Test, $* p<0.05$

Responses based on a four-point Likert scale ( 4 = "strongly agree," 3 = "agree," 2 = "disagree," and $1=$ "strongly disagree")

34 Scholarship and Practice of Undergraduate Research 
TABLE 2. Comparison of RS and URSP on Discovery Learning Outcomes

\begin{tabular}{|c|c|c|c|c|c|c|c|}
\hline Items & Group & $\mathrm{N}$ & Mean Rank & Sum of Ranks & $\begin{array}{c}\text { Mann-Whitney } \\
\text { U }\end{array}$ & Z & $\begin{array}{l}\text { Asymp. Sig. } \\
\text { (2-tailed) }\end{array}$ \\
\hline \multirow{3}{*}{$\begin{array}{l}\text { Understanding current issues in } \\
\text { your major or field of study }\end{array}$} & $\mathrm{RS}$ & 794 & 497.96 & 395377.00 & \multirow{3}{*}{74274.000} & \multirow{3}{*}{-0.813} & \multirow{3}{*}{0.416} \\
\hline & URSP & 194 & 480.36 & 93189.00 & & & \\
\hline & Total & 988 & & & & & \\
\hline \multirow{3}{*}{$\begin{array}{l}\text { Judging the quality of research } \\
\text { studies or creative works }\end{array}$} & $\mathrm{RS}$ & 792 & 488.01 & 386504.00 & \multirow{3}{*}{72476.000} & \multirow{3}{*}{-1.735} & \multirow{3}{*}{0.083} \\
\hline & URSP & 198 & 525.46 & 104041.00 & & & \\
\hline & Total & 990 & & & & & \\
\hline \multirow{3}{*}{$\begin{array}{l}\text { Explaining the advantages and } \\
\text { limitations of different methods } \\
\text { to approaching a question or } \\
\text { problem in your field }\end{array}$} & $\mathrm{RS}$ & 792 & 485.90 & 384835.00 & \multirow{3}{*}{70807.000} & \multirow{3}{*}{-2.015} & \multirow{3}{*}{$0.044 *$} \\
\hline & URSP & 196 & 529.24 & 103731.00 & & & \\
\hline & Total & 988 & & & & & \\
\hline \multirow{3}{*}{$\begin{array}{l}\text { Understanding how to add to } \\
\text { a scholarly or professional } \\
\text { conversation through research } \\
\text { and writing }\end{array}$} & $\mathrm{RS}$ & 791 & 490.74 & 388177.50 & \multirow{3}{*}{74941.500} & \multirow{3}{*}{-0.880} & \multirow{3}{*}{0.379} \\
\hline & URSP & 197 & 509.59 & 100388.50 & & & \\
\hline & Total & 988 & & & & & \\
\hline \multirow{3}{*}{$\begin{array}{l}\text { Understanding the research or } \\
\text { creative process in your field }\end{array}$} & $\mathrm{RS}$ & 793 & 490.96 & 389329.00 & \multirow{3}{*}{74508.000} & \multirow{3}{*}{-1.190} & \multirow{3}{*}{0.234} \\
\hline & URSP & 198 & 516.20 & 102207.00 & & & \\
\hline & Total & 991 & & & & & \\
\hline \multirow{3}{*}{$\begin{array}{l}\text { Understanding the difference } \\
\text { between personal beliefs and } \\
\text { evidence in supporting a } \\
\text { position or drawing conclusions }\end{array}$} & $\mathrm{RS}$ & 783 & 488.80 & 382727.00 & \multirow{3}{*}{74545.000} & \multirow{3}{*}{-0.189} & \multirow{3}{*}{0.850} \\
\hline & URSP & 192 & 484.76 & 93073.00 & & & \\
\hline & Total & 975 & & & & & \\
\hline \multirow{3}{*}{$\begin{array}{l}\text { Understanding how research is } \\
\text { relevant to what you are } \\
\text { learning in your classes }\end{array}$} & $\mathrm{RS}$ & 788 & 494.19 & 389424.00 & \multirow{3}{*}{75890.000} & \multirow{3}{*}{-0.401} & \multirow{3}{*}{0.689} \\
\hline & URSP & 196 & 485.69 & 95196.00 & & & \\
\hline & Total & 984 & & & & & \\
\hline \multirow{3}{*}{$\begin{array}{l}\text { Career- or work-related } \\
\text { knowledge and skills }\end{array}$} & $\mathrm{RS}$ & 801 & 483.55 & 387321.50 & \multirow{3}{*}{66120.500} & \multirow{3}{*}{-3.915} & \multirow{3}{*}{$0.000^{*}$} \\
\hline & URSP & 199 & 568.74 & 113178.50 & & & \\
\hline & Total & 1000 & & & & & \\
\hline
\end{tabular}

Note: Mann-Whitney U Test, $* p<0.05$

Responses based on a four-point Likert scale ( 4 = "very much," 3 = "quite a bit," 2 = "some," 1 = "very little," and 0 = "none/not applicable"; "none/not applicable" response treated as missing for means analysis)

students participate in intensive, one-on-one mentoring; some students are mentored in research teams that may be led by a faculty member, team of faculty, or graduate research assistants; some students participate in a piece of a single, class-based project; and others may work on individual courses but in the context of a RS course with other students working on their own projects. The diversity of these arrangements, the nature of scholarship in the student's discipline, individual student preparation, and other student characteristics all inform the undergraduate research experience. The survey provides useful information as part of a comprehensive assessment strategy, wherein in-depth information is collected from qualitative information (e.g., interviews and focus groups), faculty perspectives, and direct review of student work.

\section{Strengths and Limitations}

The self-report survey is a common method for assessing student experiences with undergraduate research, with exemplars from Lopatto's SURE, CURE, and RISC surveys, as well as items that allow for national comparisons from the National Survey of Student Engagement (NSSE) (http://nsse.indiana.edu/). However, a coherent, evidencebased strategy does not exist for assessing outcomes across institutions (National Academies of Sciences, Engineering, and Medicine 2017). Because the main interest is program assessment at the institution, the OSCAR Student Survey is well-suited for this purpose. It is locally developed and based on Mason's learning outcomes as created by faculty providing formative assessment data for faculty and program staff to make decisions about needs and improvements. 
TABLE 3. Comparison of RS and URSP on Scholarly Inquiry Learning Outcomes

\begin{tabular}{|c|c|c|c|c|c|c|c|}
\hline Items & Group & $\mathrm{N}$ & Mean Rank & Sum of Ranks & $\begin{array}{c}\text { Mann-Whitney } \\
\text { U }\end{array}$ & Z & $\begin{array}{l}\text { Asymp. Sig. } \\
\text { (2-tailed) }\end{array}$ \\
\hline \multirow{3}{*}{$\begin{array}{l}\text { Understanding terminology that } \\
\text { is specific to your field }\end{array}$} & RS & 797 & 489.17 & 389866.50 & \multirow{3}{*}{71863.500} & \multirow{3}{*}{-2.151} & \multirow{3}{*}{$0.031 *$} \\
\hline & URSP & 199 & 535.88 & 106639.50 & & & \\
\hline & Total & 996 & & & & & \\
\hline \multirow{3}{*}{$\begin{array}{l}\text { Matching a scholarly question } \\
\text { to the appropriate theories and } \\
\text { methods }\end{array}$} & RS & 798 & 492.17 & 392754.00 & \multirow{3}{*}{73953.000} & \multirow{3}{*}{-1.576} & \multirow{3}{*}{0.115} \\
\hline & URSP & 199 & 526.38 & 104749.00 & & & \\
\hline & Total & 997 & & & & & \\
\hline \multirow{3}{*}{$\begin{array}{l}\text { Learning ethical conduct in your } \\
\text { field }\end{array}$} & RS & 798 & 493.68 & 393960.00 & \multirow{3}{*}{75159.000} & \multirow{3}{*}{-1.220} & \multirow{3}{*}{0.223} \\
\hline & URSP & 199 & 520.32 & 103543.00 & & & \\
\hline & Total & 997 & & & & & \\
\hline \multirow{3}{*}{$\begin{array}{l}\text { Collecting appropriate data } \\
\text { or evidence for the research } \\
\text { question or creative purpose }\end{array}$} & RS & 798 & 498.89 & 398117.50 & \multirow{3}{*}{79316.500} & \multirow{3}{*}{-0.025} & \multirow{3}{*}{0.980} \\
\hline & URSP & 199 & 499.42 & 99385.50 & & & \\
\hline & Total & 997 & & & & & \\
\hline \multirow{3}{*}{$\begin{array}{l}\text { Dealing with obstacles faced in } \\
\text { the research or creative process }\end{array}$} & RS & 797 & 484.77 & 386359.00 & \multirow{3}{*}{68356.000} & \multirow{3}{*}{-3.278} & \multirow{3}{*}{$0.001 *$} \\
\hline & URSP & 199 & 553.50 & 110147.00 & & & \\
\hline & Total & 996 & & & & & \\
\hline \multirow{3}{*}{$\begin{array}{l}\text { Analyzing data and information } \\
\text { relevant to the project }\end{array}$} & $\mathrm{RS}$ & 790 & 441.84 & 349052.00 & \multirow{3}{*}{36607.000} & \multirow{3}{*}{-11.727} & \multirow{3}{*}{$0.000 *$} \\
\hline & URSP & 195 & 700.27 & 136553.00 & & & \\
\hline & Total & 985 & & & & & \\
\hline \multirow[t]{3}{*}{ Writing clearly and effectively } & RS & 790 & 447.17 & 353266.00 & \multirow{3}{*}{40821.000} & \multirow{3}{*}{-10.517} & \multirow{3}{*}{$0.000 *$} \\
\hline & URSP & 195 & 678.66 & 132339.00 & & & \\
\hline & Total & 985 & & & & & \\
\hline \multirow{3}{*}{$\begin{array}{l}\text { Evaluating scholars' positions } \\
\text { or statements to determine how } \\
\text { well-supported by evidence } \\
\text { they are }\end{array}$} & RS & 790 & 455.10 & 359529.00 & \multirow{3}{*}{47084.000} & \multirow{3}{*}{-8.682} & \\
\hline & URSP & 195 & 646.54 & 126076.00 & & & $0.000 *$ \\
\hline & Total & 985 & & & & & \\
\hline Communicating well orally in & $\mathrm{RS}$ & 790 & 452.85 & 357754.50 & & & \\
\hline $\begin{array}{l}\text { a presentation, performance, or } \\
\text { discussion of your work }\end{array}$ & URSP & 195 & 655.64 & 127850.50 & 45309.500 & -9.193 & $0.000 *$ \\
\hline & Total & 985 & & & & & \\
\hline
\end{tabular}

Note: Mann-Whitney U Test, $* p<0.05$

Responses based on a four-point Likert scale ( 4 = "very much," 3 = "quite a bit," 2 = "some," 1 = "very little," and 0 = "none/not applicable"; "none/not applicable" response treated as missing for means analysis)

The survey is administered to all students participating in an OSCAR course or experience, so data are collected from a broad student sample from across the institution. In addition to students who take an OSCAR course, all students in UNIV 100 and ENGH 302 also receive the survey, which creates the potential for comparison study after graduation between students who did and did not participate in OSCAR activities. Tracking responses by student ID allows us to merge with student-level demographics and institutional data, as well as match responses with other institutional surveys. The possibility exists for a longitudinal study to assess program impacts over time.
There are limitations to the OSCAR Student Survey common to self-report surveys. Particular concerns are less than ideal response rates, nonresponse bias, and response ceiling effects. Response rates for the OSCAR Student Survey are low for RS participants (30 percent) but much higher for URSP respondents (58 percent). Response rates for voluntary surveys have been declining for years, most likely due to survey fatigue (Porter, Whitcomb, and Weitzer 2004). Two issues emerge from low response rates in this case. First, the low response rates limit the potential for conducting a true longitudinal analysis. Ideally, there would be data points from students 
TABLE 4. Comparison of RS and URSP on Creation of Scholarship (Research- and Scholarship-Intensive) Learning Outcomes

\begin{tabular}{|c|c|c|c|c|c|c|c|}
\hline Items & Group & $\mathrm{N}$ & Mean Rank & Sum of Ranks & $\begin{array}{c}\text { Mann-Whitney } \\
\text { U }\end{array}$ & Z & $\begin{array}{l}\text { Asymp. Sig. } \\
\text { (2-tailed) }\end{array}$ \\
\hline \multirow{3}{*}{$\begin{array}{l}\text { Articulating the broad } \\
\text { implications or "big picture" } \\
\text { of what you learned in the } \\
\text { course or project }\end{array}$} & $\mathrm{RS}$ & 790 & 445.51 & 351953.50 & \multirow{3}{*}{39508.500} & \multirow{3}{*}{-10.893} & \multirow{3}{*}{$0.000^{*}$} \\
\hline & URSP & 195 & 685.39 & 133651.50 & & & \\
\hline & Total & 985 & & & & & \\
\hline \multirow{3}{*}{$\begin{array}{l}\text { Creating new ideas, solutions, } \\
\text { or creative works based on } \\
\text { what you learned in the course } \\
\text { or experience }\end{array}$} & RS & 790 & 444.96 & 351514.50 & \multirow{3}{*}{39069.500} & \multirow{3}{*}{-11.014} & \multirow{3}{*}{$0.000^{*}$} \\
\hline & URSP & 195 & 687.64 & 134090.50 & & & \\
\hline & Total & 985 & & & & & \\
\hline
\end{tabular}

Note: Mann-Whitney U Test, $* p<0.05$

Responses based on a four-point Likert scale ( 4 = "very much," 3 = "quite a bit," 2 = "some," 1 = "very little," and 0 = "none/not applicable"; "none/not applicable" response treated as missing for means analysis)

TABLE 5. Comparison of RS and URSP on Personal Development

\begin{tabular}{|c|c|c|c|c|c|c|c|}
\hline Items & Group & $\mathrm{N}$ & Mean Rank & Sum of Ranks & $\begin{array}{c}\text { Mann-Whitney } \\
\text { U }\end{array}$ & Z & $\begin{array}{l}\text { Asymp. Sig. } \\
\text { (2-tailed) }\end{array}$ \\
\hline \multirow{3}{*}{$\begin{array}{l}\text { Confidence in your ability to } \\
\text { do well in future courses in } \\
\text { your major }\end{array}$} & $\mathrm{RS}$ & 789 & 483.03 & 381107.50 & \multirow{3}{*}{69452.500} & \multirow{3}{*}{-2.118} & \multirow{3}{*}{$0.034 *$} \\
\hline & URSP & 194 & 528.50 & 102528.50 & & & \\
\hline & Total & 983 & & & & & \\
\hline \multirow{3}{*}{$\begin{array}{l}\text { Relating well to people of } \\
\text { different races, nations, and } \\
\text { religions }\end{array}$} & RS & 789 & 483.59 & 381555.00 & \multirow{3}{*}{69900.000} & \multirow{3}{*}{-1.946} & \multirow{3}{*}{0.052} \\
\hline & URSP & 194 & 526.19 & 102081.00 & & & \\
\hline & Total & 983 & & & & & \\
\hline \multirow{3}{*}{$\begin{array}{l}\text { Comfort in working } \\
\text { collaboratively with others }\end{array}$} & $\mathrm{RS}$ & 788 & 488.82 & 385193.00 & \multirow{3}{*}{74327.000} & \multirow{3}{*}{-0.623} & \multirow{3}{*}{0.533} \\
\hline & URSP & 194 & 502.37 & 97460.00 & & & \\
\hline & Total & 982 & & & & & \\
\hline \multirow{3}{*}{$\begin{array}{l}\text { Being patient with the pace of } \\
\text { research or creative discovery }\end{array}$} & RS & 789 & 476.16 & 375686.50 & \multirow{3}{*}{64031.500} & \multirow{3}{*}{-3.715} & \multirow{3}{*}{$0.000 *$} \\
\hline & URSP & 194 & 556.44 & 107949.50 & & & \\
\hline & Total & 983 & & & & & \\
\hline \multirow{3}{*}{$\begin{array}{l}\text { Confidence in your ability to } \\
\text { contribute to your field }\end{array}$} & RS & 789 & 482.57 & 380748.50 & \multirow{3}{*}{69093.500} & \multirow{3}{*}{-2.231} & \multirow{3}{*}{$0.026^{*}$} \\
\hline & URSP & 194 & 530.35 & 102887.50 & & & \\
\hline & Total & 983 & & & & & \\
\hline \multirow[t]{3}{*}{ Managing your time effectively } & $\mathrm{RS}$ & 789 & 484.15 & 381996.00 & \multirow{3}{*}{70341.000} & \multirow{3}{*}{-1.834} & \multirow{3}{*}{0.067} \\
\hline & URSP & 194 & 523.92 & 101640.00 & & & \\
\hline & Total & 983 & & & & & \\
\hline \multirow[t]{3}{*}{ Maintaining a curious attitude } & $\mathrm{RS}$ & 789 & 482.14 & 380407.50 & \multirow{3}{*}{68752.500} & \multirow{3}{*}{-2.348} & \multirow{3}{*}{$0.019^{*}$} \\
\hline & URSP & 194 & 532.11 & 103228.50 & & & \\
\hline & Total & 983 & & & & & \\
\hline
\end{tabular}

Note: Mann-Whitney U Test, $* p<0.05$

Responses based on a four-point Likert scale ( 4 = "very much," 3 = "quite a bit," 2 = "some," and 1 = "very little"; "none/not applicable" response treated as missing)

throughout their college experience, allowing a view of their development over time and thus an understanding of patterns in their attitudes and learning. Second, nonrespondents may differ from respondents, creating a potential nonresponse bias in the data; thus, if there is a pattern to nonrespondent behavior, the survey cannot be used to understand their experiences. Another limitation concerns the high-level agreement on attitudinal items. 
This could represent a response ceiling effect, wherein students report consistently high attitudes from their first year, and the potential to see growth or change is limited. Given the survey's role as an assessment instrument, it would be difficult to make claims about how the experience with undergraduate research made a difference for students in this respect. Finally, the ability of students to accurately self-report on their learning in a survey instrument has been contested (Porter 2013). To mitigate selfreport issues, Porter's (2013) five conditions for valid self-report data were followed: the information is known to participants, questions are phrased clearly, the items refer to recent activities, respondents take the questions seriously, and students do not face threat or embarrassment by answering the questions.

To address these limitations, information from the survey was triangulated with information from other assessment strategies, including faculty reviews of student work, and interviews and focus groups with students. Past qualitative assessment studies have revealed crucial insights that have been used to inform student programming and curriculum development efforts.

\section{Implications for Use in Program Assessment}

The OSCAR Student Survey is a tool that is used as an important element in a comprehensive program-level assessment strategy. The key to its successful use is the high degree of relevance to OSCAR and the institution. The items align with the program's carefully crafted student learning outcomes, which allows mapping of the results to determine the program's strengths, understand where students are thriving and needing support, and make decisions about targets for resources. Survey data are shared with faculty online through a searchable, multiyear database. Faculty are notified each semester when the data are available so that they may apply the results to their courses. Aggregated data are available to the university community by Discovery, Inquiry, RS, and URSP course grouping so that anyone can use the data for program planning.

One program pillar is its focus on faculty development. Students as Scholars engages faculty in supportive learning communities to promote inquiry-based teaching and mentoring across the disciplines. The signature activity is the Scholarship Development Grant (SDG), which provides faculty development workshops, one-on-one consultations, and funds to create or redesign RS courses, and develop Discovery or Inquiry courses or multidisciplinary research projects. The OSCAR Student Survey results have been used to identify needs for the program's faculty development efforts to support faculty and faculty teams to create and sustain courses and scaffolded curricula that support students at the right levels. For example, survey results have been presented to mixed groups of faculty, including those with experience teaching RS courses and those without such experience. Faculty are asked to weigh the survey results and consider how the concepts are used in their classes. Experienced faculty generally conclude that their students take longer and experience more challenges with developing reasonable scholarly questions, collecting and analyzing data, and learning how to present data. Faculty reason that, in their experience, self-selected students who work one-on-one with a faculty mentor tend to achieve more, faster than students in course-based experiences. Faculty are encouraged to design RS courses to strive for student achievement of the learning outcomes, while using available information to understand their students' particular starting points and needs.

It is important that assessment data are used to inform program improvement. At Mason, multiple assessment strategies are used to inform OSCAR's institution-wide faculty and curriculum development efforts. In terms of the results presented here, observed differences between the RS and URSP student responses are not of concern; students who self-select into a mentored research program tend to be altogether more motivated, enthusiastic, and prepared for conducting research projects than students who enroll in a required senior capstone course. The highly positive attitudes toward research that students report across campus in both RS and URSP experiences are encouraging. As previously mentioned, results from the OSCAR Student Survey were applied to a few qualitative studies so that more could be learned about the student experience. One study sought to understand RS students' definitions and perceptions of the word research, whereas another interviewed URSP graduates about the role of curiosity in their motivations to start, sustain, and complete independent research projects. Findings have been used from these qualitative studies primarily in faculty development workshops and student recruitment presentations.

\section{Future Plans}

Although the OSCAR Student Survey was designed as a program assessment tool, the data also will be used as part of a longitudinal study to understand larger questions about the impact of undergraduate research on student development. Applying five years of participation and survey data, an analytical model is in process that will include student-level responses from NSSE and institutional surveys, including the Graduating Senior Survey, Career Plans Survey, and Alumni Survey. The possibilities are being explored for a longitudinal analysis that works with the complexities of existing data as well as missing data points. Ultimately, support for effective institutional decision-making and planning for student success is the goal, so that diverse student populations can be best served, including transfer students and students in fields that have not previously been well captured for undergraduate research (such as business; the humanities; 
nursing; the visual and performing arts; the social sciences; and professional fields such as business, social work, and nursing. These insights can assist in developing innovative approaches to reach more students on more campuses, so that the benefits of this high-impact practice can have a wider impact.

\section{References}

Cornell University Office of Institutional Research. 2011. Cornell PULSE Survey [survey instrument]. Ithaca, NY: Author. Accessed November 22, 2011. http://irp.dpb.cornell.edu/surveys/ pulse-surveys

George Mason University Office of Institutional Assessment. 2012. Graduating Senior Survey 2012-2013 [unpublished survey instrument]. Fairfax, VA: Author.

George Mason University Office of Institutional Assessment. 2016. Graduating Senior Survey 2015-2016 [unpublished data results]. Fairfax, VA: Author.

George Mason University Students as Scholars Initiative. 2016. Students as Scholars Program Rubric Version 2. Fairfax, VA: Author. Retrieved from https://ira.gmu.edu/student-as-scholars/ outcomes-rubrics/

Gettysburg College. 2011. Mellon Summer'11 Scholars Program Assessment Questionnaire [unpublished survey instrument]. Gettysburg, PA: Author.

Kuh, George D. 2008. High-Impact Educational Practices: What They Are, Who Has Access to Them, and Why They Matter. Washington, DC: Association of American Colleges and Universities.

Lopatto, David. 2004. "Survey of Undergraduate Research Experiences (SURE): First Findings." Cell Biology Education 3: 270277. doi: 10.1187/cbe.04-07-0045

Lopatto, David. 2010. Science in Solution: The Impact of Undergraduate Research on Student Learning. Washington, DC: Council on Undergraduate Research.

Lopatto, David. 2012a. Classroom Undergraduate Research Experience (CURE) Survey [survey instrument]. Accessed March 16, 2012. https://www.grinnell.edu/academics/areas/psychology/assessments/cure-survey

Lopatto, David. 2012b. Research on the Integrated Science Curriculum (RISC) Survey [survey instrument]. Accessed March 16, 2012. https://www.grinnell.edu/academics/areas/psychology/ assessments/risc-survey

Lopatto, David. 2012c. Survey of Undergraduate Research Experiences (SURE III) [survey instrument]. Accessed March 16, 2012. https://www.grinnell.edu/academics/areas/psychology/ assessments/sure-iii-survey
National Academies of Sciences, Engineering, and Medicine. 2017. Undergraduate Research Experiences for STEM Students: Successes, Challenges, and Opportunities. Washington, DC: National Academies Press. doi: 10.17226/24622

Porter, Stephen R. 2013. "Self-Reported Learning Gains: A Theory and Test of College Student Survey Response." Research in Higher Education 54: 201-26. Accessed November 2, 2012. doi: 10.1007/s11162-012-9277-0

Porter, Stephen R., Michael E. Whitcomb, and William H. Weitzer. 2004. "Multiple Surveys of Students and Survey Fatigue." New Directions for Institutional Research 121: 63-73. doi: 10.1002/ir.101

Spronken-Smith, Rachel, Rebecca Walker, Julie Batchelor, Billy O'Steen, and Tom Angelo. 2012. "Evaluating Student Perceptions of Learning Processes and Intended Learning Outcomes Under Inquiry Approaches." Assessment \& Evaluation in Higher Education 37: 57-72. doi: 10.1080/02602938.2010.496531

Willis, Gordon B. 1999. "Cognitive Interviewing: A 'How To' Guide." Workshop presented at the annual meeting of the American Statistical Association, Baltimore, August 8-12.

\section{Stephanie L. Foster}

George Mason University, sfoste21@gmu.edu

Stephanie L. Foster is associate director for undergraduate education at George Mason University. She serves as the lead assessment scholar for Mason's Students as Scholars undergraduate research initiative. Foster works with faculty across the disciplines to support student learning through learning outcomes assessment, program evaluation, and curriculum development. She has taught in the Honors College and mentors graduate students in the Higher Education program. She earned a PhD at the University of Georgia's Institute of Higher Education and a MA in higher education from the University of Arizona.

Bethany M. Usher is associate provost for undergraduate education at George Mason University. She takes students to cemeteries, where they investigate from both osteological and archaeological perspectives to understand the social structure and health of past communities. She served as founding director of Mason's Students as Scholars initiative, cochaired the CUR Conference in 2014, and chairs CUR's Undergraduate Research Programs Division. Prior to joining Mason, she was a faculty member of biological anthropology and past chair of the Anthropology Department at the State University of New York at Potsdam, where she established the Center for Undergraduate Research and served as its director. 